\title{
Sugar, Acid Soluble Polysaccharide, and Total Phenolic Contents in Tropical Legumes and Their Relationships with In Vitro Nutrient Fermentability
}

\author{
A. Ikhwanti ${ }^{\mathrm{a}, \mathrm{d}, \mathrm{e}}$, A. Jayanegara ${ }^{\mathrm{a}, \mathrm{b}}$, I. G. Permana ${ }^{\mathrm{b}}$, W. W. Wardania ${ }^{\mathrm{a}, \mathrm{e}}$, Y. Retnani $^{\mathrm{b}}$, \& A. A. Samsudin $^{\mathrm{c}, *}$ \\ ${ }^{a}$ Animal Feed and Nutrition Modelling (AFENUE) Research Group, Department of Nutrition and Feed Technology, \\ Faculty of Animal Science, IPB University (Bogor Agricultural University) \\ bDepartment of Nutrition and Feed Technology, Faculty of Animal Science, IPB University \\ (Bogor Agricultural University) \\ Jalan Agatis, Kampus IPB Dramaga, Bogor 16680, Indonesia \\ cDepartment of Animal Science, Faculty of Agriculture, Universiti Putra Malaysia, \\ Serdang Selangor Dahrul Ehsan 43400 Malaysia \\ dGraduate Study Program of Nutrition and Feed Science, IPB University (Bogor Agricultural University) \\ Jalan Agatis, Kampus IPB Dramaga, Bogor 16680, Indonesia \\ eNutricell R\&D, Cibis Nine 12th Floor Unit G1, \\ Jalan TB. Simatupang No. 2, Jakarta 12560, Indonesia \\ ${ }^{*}$ Corresponding author: anjas@upm.edu.my \\ (Received 22-03-2020; Revised 03-07-2020; Accepted 15-07-2020)
}

\begin{abstract}
Tropical legume is a type of C4 plant that has been adaptive to hot environments. Therefore, tropical legumes require energy reserves in the form of sugar and starch. This study aimed to explain the relationship between sugar, starch, and tannin contents of tropical legumes and their in vitro fermentation profiles. Samples of Bauhinia purpurea, Pterocarpus indicus, Tamarindus indica, Calopogonium mucunoides, Macroptilium atropurpureum, and Stylosanthes guianensis were tested by proximate analysis, Van Soest, and in vitro nutrient fermentability. The in vitro fermentability consisted of dry matter degradability (DMD), organic matter degradability (OMD), volatile fatty acid (VFA), methane and ammonia concentrations, and gas production. The gas production kinetics were determined as gas production from soluble nutrient (a), maximum gas production $(a+b)$, and rate of gas production (c). All samples were tested using the orthogonal contrast test to compare in vitro fermentability characteristics between the different types of legumes and their tannin contents. Results revealed that the average content of the legumes dry matter examined was $22 \%$ with $\mathrm{CP}$ content of $15 \%-28 \%$. The legumes in this study had average content of $3.74 \%$ sugar, $21.86 \%$ ASP, and $0.3 \%$ total phenolics (dry matter basis). Acid soluble polysaccharides content in legumes had a positive correlation with degradability, ammonia concentration, and total gas production $(\mathrm{p}<0.05)$. However, sugar content did not have a correlation with the other in vitro fermentation characteristics. The exploration of sugar and acid soluble polysaccharides content in tropical legumes might be profitable as these nutrients could increase feeding efficiency. Sugar did not have a significant relationship to the characteristics of fermentation, on the contrary, acid soluble polysaccharides had a very close relationship to the characteristics of fermentation. The total phenolics had a close relationship with the production of VFA and ammonia. Tree legumes have better digestibility than shrub legumes.
\end{abstract}

Keywords: fermentation; sugar; legume; acid soluble polysaccharides; tropics

\section{INTRODUCTION}

One effort to maintain the sustainability of ruminant livestock business is maintaining the availability of feed. Climate change is an issue in realizing food security efforts. The negative impacts that can occur due to climate change are drought, changes in rainfall, and an abundance of $\mathrm{CO}_{2}$ concentrations in the air. One anticipation of the abundance of $\mathrm{CO}_{2}$ concentrations is to explore plants that have an efficient photosynthesis process. The $\mathrm{C} 4$ plant is a type of plant that can bind $\mathrm{CO}_{2}$ through phosphoenolpyruvate (PEP) enzyme to form four carbons compound (oxaloacetic acid). The C4 plants have higher photosynthetic rates than C3 plants, especially in high light intensity. Furthermore, C4 plants can generally grow in hot regions, for example, tropical plants, one of which is tropical legumes.

Sugar and starch are non-structural carbohydrates that are stored by plants as energy reserves. The C4 plants produce more energy in the process of photosynthesis compared to C3 plants, because tropical plants have higher starch content and are stored in leaves (Hall, 2014). Sugar and starch content in plants is important to be analyzed in order to determine the potential of a plant in meeting the nutrient requirements for these plants and the animals that consume them. Forages 
(grasses and legumes) contain structural carbohydrates (cellulose and hemicellulose) and non-structural carbohydrates. Sugar and starch are found in the contents of plant cells, while cellulose and hemicellulose are found in plant cell walls. Dickhoefer et al. (2018) studied that starch derived from legumes can avoid rumen degradation so that it can be digested and absorbed optimally in the small intestine. The legume starch granules are resistant to hydrolysis of amylase due to the degree of crystallinity (Alcázar-alay \& Meireles, 2015).

Tropical legume is one type of forage used as a source of protein for livestock. In general, tropical legumes are adaptive to tropical climates. Junior et al. (2020) stated legumes could be divided into two types, namely tree legumes and shrub legumes based on the growth characteristics. There are several species of tropical legumes that have not been explored and studied on the relationship of nutritional values to in vitro parameters, for example, Bauhinia purpurea, Pterocarpus indicus, Tamarindus indica, Calopogonium mucunoides, Macroptilium atropurpureum, and Stylosanthes guianensis. Legumes are identical with higher protein content and degradability compared to grass (Heinritz et al. 2012). In general, legumes contain anti-nutritive components. The presence of anti-nutritive components within normal limits can increase the availability of rumen undegradable protein (RUP) so that the available protein that is easily absorbed by the small intestine will increase. Grabber (2009) studied the prediction of rumen undegradable protein value in forage legumes containing protein-binding polyphenols. The tannin content in legumes can alter rumen degradable protein (RDP) into RUP so that it can reduce methane gas production from rumen fermentation in ruminants (Focant et al., 2018).

In the in vitro fermentation parameters, Pino \& Heinrichs (2016) explained that the starch component in the feed will produce a VFA product that significantly increased at 0 to 4 hours (reached $180 \mathrm{mM}$ ) after feeding, then the VFA production decreases. This is in accordance with a study by Hatew et al. (2015), which showed that the use of slowly fermentable starch produced methane of $48.4 \mathrm{~mL} / \mathrm{g} \mathrm{OM}$ incubated, while with the same level and measurement time, rapidly fermentable starch produced methane gas of $36.8 \mathrm{~mL} / \mathrm{g}$ $\mathrm{OM}$ incubated. In the previous study, most of sugar and starch analysis were used for food grade raw materials, but in this study, they were analyzed from feedstuffs to increase ruminant feed efficiency by understanding sugar and starch contents of legumes. To our knowledge, sugar and starch contents in tropical legumes, particularly originated from South East Asian countries have not been investigated and reported. This study aimed to explain the relationship between sugar, starch, and tannin contents of tropical legumes and their in vitro fermentation profiles.

\section{MATERIALS AND METHODS}

\section{Sample Preparation}

The screened legume data were collected, then 6 types of legumes (B. purpurea, P. indicus, T. indica, C. mucunoides, M. atropurpureum, and S. guianensis) were obtained which had not been explored in terms of sugar, starch, and tannin contents and their relationships to in vitro nutrient fermentability. A total of $2 \mathrm{~kg}$ of legumes that can be consumed by livestock (edible parts) from each type of legume were collected. The tree legumes collection was performed by cutting the young leaves and stems, while the shrub legumes collection was performed by cutting the crowns. Cutting was performed with a length of $\pm 5 \mathrm{~cm}$. Plants were air dried in a greenhouse for 2-3 days, then followed by drying with an oven at $60^{\circ} \mathrm{C}$ for 1 day. Dried plants were ground by using a grinder with a screen diameter of $1 \mathrm{~mm}$.

\section{Procedure of Chemical Composition Analysis}

Proximate analysis (AOAC, 2005) and Van Soest et al. (1991) were used to determine the nutrient compositions of six legumes. The proximate analysis consisted of dry matter (DM), ash, crude protein (CP), ether extract (EE), crude fiber (CF), and nitrogen-free extract (NFE). Dry matter and ash measurements were carried out using a $105^{\circ} \mathrm{C}$ oven and a $550-600^{\circ} \mathrm{C}$ furnace, respectively. Crude fiber fraction analysis (Van Soest et al., 1991) consists of Neutral detergent fiber (NDF), Acid detergent fiber (ADF), and Acid detergent lignin (ADL).

\section{Analysis of Sugar, Starch, and Total Phenolic Compounds}

Total sugar content analysis used the Anthrone method, as was suggested by Bawazeer et al. (2017). Acid hydrolyzed polysaccharides content was analyzed by using the method of Duan et al. (2012) and its modification.

The total phenolic content analysis used the Petchidurai et al. (2019) method. Total phenolic compound content analysis was carried out by adding $10 \mathrm{mg}$ of leaf powder with distilled water to a volume of 100 $\mathrm{mL}$. Then, the solution was put into a $10 \mathrm{~mL}$ volumetric flask and $1 \mathrm{~mL}$ of Folin Ciocalteu reagent was added, then the solution was shaken and waited for 5 minutes. After that, $2 \mathrm{~mL}$ of $15 \% \mathrm{Na}_{2} \mathrm{CO}_{3}$ was added to the solution and the solution was shaken homogeneously and waited for 5 minutes. The solution was added with distilled water to exactly $10 \mathrm{~mL}$ and then measured at wavelengths from 500 to $900 \mathrm{~nm}$.

\section{Analysis of In Vitro Rumen Fermentation Characteristics}

In vitro gas production was evaluated according to the method by Menke \& Steingass (1988). An amount of $200 \mathrm{mg}$ sample dry matter was put into a lubricated syringe. Previously, the lower end of the syringe was closed by using a clip. A buffer solution was produced by combining ingredients, which consisted of rumen liquid under anaerobic conditions at $39^{\circ} \mathrm{C}$, micro minerals, macro minerals, buffer solutions, resazurin solutions, reducing solutions (must be prepared at any time), and distilled water. The buffer solution was mixed with rumen liquid at a ratio of $2: 1$. The mixture 
was prepared and put in $39^{\circ} \mathrm{C}$ water, and then the mixture was stirred continuously under anaerobic conditions. A total of $30 \mathrm{~mL}$ of rumen buffer solution was put into each tube containing the sample. Each treatment was analyzed in four replications and three incubations. Waterbath shaker was maintained at $39^{\circ} \mathrm{C}$. Observation of total gas production was carried out and recorded at $0,3,6,9,12,24,48$, and 72 incubation hours.

The gas production kinetic was estimated with an exponential equation (Orskov \& McDonald, 1979):

$$
\mathrm{p}=\mathrm{a}+\mathrm{b}\left(1-\mathrm{e}^{-\mathrm{ct}}\right)
$$

where $\mathrm{p}$ was cumulative gas production at $\mathrm{t}$ hour, $\mathrm{a}$ was gas production from the soluble fraction, $b$ was gas production from the insoluble fraction but can be fermented, and c was the rate of gas production.

After an incubation period of 24 hours, each legume sample was taken as many as 2 syringes, then the sample was analyzed to determine the degradabilities of DM and OM, and rumen fluid (for VFA and $\mathrm{NH}_{3}$ analysis). VFA determination used gas chromatography (Hewlett Packard 6890 GC system) at 24 hours incubation time according to the Azizi et al. (2020) procedure. Then, ammonia was determined according to Cabeza et al. (2018).

The substrate was filtered to separate from the buffer solution by using sintered glass. Vacuum pump filtering was performed to remove water residues. Then, the substrate was put into a $105^{\circ} \mathrm{C}$ oven for 24 hours. Then, the sintered glass was removed from the oven and put into a desiccator before being weighed. After that, the sintered glass was put into a $550^{\circ} \mathrm{C}-600^{\circ} \mathrm{C}$ oven for 3 hours and put in a desiccator before weighing was performed.

Estimated methane gas production was based on the calculation of Moss et al. (2000):

$$
\mathrm{CH}_{4}=0.45 \mathrm{C}_{2}-0.275 \mathrm{C}_{3}+0.40 \mathrm{C}_{4}
$$

where C2 was acetate, C3 was propionate, and C4 was butyrate.

\section{Statistical Analysis}

The data obtained were statistically analyzed by using analysis of variance (ANOVA) with Randomized Complete Block Design (RCBD) with the rumen incubation time as the block. If there were significant differences, then Duncan test was conducted (Riadi, 2016). An orthogonal contrast test was performed as a comparison method between groups of plants. Treatment groups were differentiated based on tannin content and type of legumes. Data analysis was performed using SPSS 16.0 software.

\section{RESULTS}

\section{Nutrient Composition}

Table 1 presents the results that averages DM and $\mathrm{CP}$ contents of tree legume were higher than those of shrub legume. The range of CP contents in all legumes tested was $16 \%-28 \%$ of DM. B. purpurea had the highest DM content. CP content of S. guianensis was $16.74 \%$ that was relatively lower than that of the other legumes. Based on the data presented, S. guianensis had the highest CF content $(42.18 \%)$ compared to the other legume types, and the average CF content of tree legume was lower than that of shrub legume. $M$. atropurpureum had the highest proportion content of NDF and ADF. On the other hand, T. indica relatively had the lowest NDF and ADF contents.

\section{Sugar, Acid Soluble Polysaccharides (ASP), and Total Phenolics Contents}

Table 2 shows that sugar content is lower than starch content. C. mucunoides had the highest content of sugar, whereas S. guianensis had the lowest content of sugar. The ASP contents of some legume species (Table 2) were lower than the ASP content in cereals. Tannin is an anti-nutritive compound that is commonly found in

Table 1. Nutrient composition of tropical legumes (\% DM)

\begin{tabular}{lcrrrrr}
\hline \multirow{2}{*}{ Nutrients } & \multicolumn{9}{c}{ Tropical legumes } \\
\cline { 2 - 7 } & BP & PI & TI & CM & MA & SG \\
\hline Common name & Bunga kupu & Angsana & Asem & Kalopo & Siratro & Stilo \\
Type of legumes & Tree & Tree & Tree & Shrub & Shrub & Shrub \\
DM & 24.74 & 24.31 & 27.28 & 18.80 & 21.04 & 20.64 \\
Ash & 11.18 & 5.93 & 10.13 & 6.67 & 6.81 & 5.83 \\
CP & 28.95 & 28.91 & 15.89 & 19.69 & 17.87 & 16.74 \\
EE & 2.45 & 0.87 & 2.95 & 2.20 & 1.22 & 0.62 \\
CF & 23.09 & 25.20 & 19.75 & 28.65 & 28.65 & 42.18 \\
NFE & 34.33 & 39.09 & 51.28 & 42.79 & 42.66 & 34.63 \\
NDF & 57.57 & 67.19 & 52.79 & 67.96 & 80.62 & 73.46 \\
ADF & 29.29 & 35.51 & 30.60 & 35.82 & 49.54 & 48.86 \\
ADL & 0.27 & 0.54 & 0.44 & 0.45 & 0.51 & 0.33 \\
\hline
\end{tabular}

Note: $\mathrm{BP}=$ Bauhinia purpurea, $\mathrm{PI}=$ Pterocarpus indicus, $\mathrm{TI}=$ Tamarindus indica, $\mathrm{CM}=$ Calopogonium mucunoides, $\mathrm{MA}=$ Macroptilium atropurpureum, $\mathrm{SG}=$ Stylosanthes guianensis, $\mathrm{DM}=$ dry matter, $\mathrm{CP}=$ crude protein, $\mathrm{EE}=$ ether extract, $\mathrm{CF}=$ crude fiber, $\mathrm{NFE}=$ nitrogen-free extract, $\mathrm{NDF}=$ neutral detergent fiber, $\mathrm{ADF}=$ acid detergent fiber, $\mathrm{ADL}=$ acid detergent lignin. 
legumes. Table 2 shows the total phenolics content of the six legume plants is $\leq 0.5 \%$ of DM. The averages of sugar and ASP were $3.74 \%$ and $21.86 \%$, respectively.

\section{In Vitro Ruminal Fermentation Characteristics}

T. indica legume which had a high starch content of $26.33 \%$ of DM and low fiber fraction (NDF and ADF) produced a high rate of gas production of $0.067 \mathrm{~mL} /$ hour $(\mathrm{p}<0.05)$ and the high degradability percentage $(p<0.001)$. Total VFA content was more than $30 \mathrm{mM}$ in all samples, in order of proportion from the largest to

Table 2. Sugar, starch, and tannin contents in legumes

\begin{tabular}{ccccc}
\hline Legumes & $\begin{array}{c}\text { Category of } \\
\text { legume }\end{array}$ & $\begin{array}{c}\text { Sugar } \\
(\% \text { DM) }\end{array}$ & $\begin{array}{c}\text { Starch } \\
(\% \mathrm{DM})\end{array}$ & $\begin{array}{c}\text { Tannin } \\
(\% \mathrm{DM})\end{array}$ \\
\hline BP & Low tannin & 3.38 & 16.52 & 0.14 \\
PI & High tannin & 3.43 & 21.86 & 0.50 \\
TI & High tannin & 3.22 & 26.33 & 0.35 \\
CM & Low tannin & 8.77 & 23.49 & 0.14 \\
MA & High tannin & 2.09 & 18.27 & 0.40 \\
SG & Low tannin & 1.55 & 24.69 & 0.19 \\
\hline
\end{tabular}

Note: $\mathrm{BP}=$ Bauhinia purpurea, $\mathrm{PI}=$ Pterocarpus indicus, $\mathrm{TI}=$ Tamarindus in dica, $\mathrm{CM}=$ Calopogonium mucunoides, $\mathrm{MA}=$ Macroptilium atropurpureum, $\mathrm{SG}=$ Stylosanthes guianensis, $\mathrm{DM}=$ dry matter. the smallest one was $\mathrm{C}_{2}$ (acetate), $\mathrm{C}_{3}$ (propionate), and $\mathrm{C}_{4}$ (butyrate). Acetate proportion of those samples was more than $72 \%$ of total VFA and propionate was more than $16 \%$. All samples produced methane concentration below $12 \mathrm{mM}$. The ammonia produced in the experiments varied on 13 up to $18 \mathrm{mmol} / \mathrm{L}$ (Table 3 ).

During the incubation period of 12 to 72 hours, gas production increased (Table 4). S. guianensis had the highest total gas production at each incubation time. Otherwise, M. atropurpureum had the lowest total gas production at each incubation time. T. indica had the highest production of dissolved fraction gas (a) and the rate of gas production (c) (Table 5). Table 6 determined that sugar and protein contents did not significantly correlate with in vitro parameters. In contrast, starch and tannin contents had a significant correlation with ammonia production. All in vitro parameters were significantly different $(p<0.05)$ between plants with high and low tannins, except the maximum gas production and the rate of gas production.

\section{DISCUSSION}

A legume can substitute another legume by viewing the degradability parameter. The percentages of OMD of several legumes are equivalent to that

Table 3. Percentage of degradability, VFA concentration, methane gas production, and ammonia of tropical legumes

\begin{tabular}{|c|c|c|c|c|c|c|c|c|}
\hline \multirow{2}{*}{ Variables } & \multicolumn{6}{|c|}{ Tropical legumes } & \multirow{2}{*}{ SEM } & \multirow{2}{*}{$\mathrm{p}$ value } \\
\hline & $\mathrm{BP}$ & PI & $\mathrm{TI}$ & $\mathrm{CM}$ & MA & SG & & \\
\hline DMD (\%) & $46.02 \pm 0.43^{b}$ & $42.42 \pm 1.39^{c}$ & $54.25 \pm 1.29^{a}$ & $46.68 \pm 0.45^{b}$ & $30.03 \pm 0.30^{\mathrm{d}}$ & $48.22 \pm 0.13^{b}$ & 1.67 & $<0.001$ \\
\hline OMD (\%) & $51.13 \pm 0.05^{\mathrm{b}}$ & $53.72 \pm 0.08^{\mathrm{ab}}$ & $56.18 \pm 0.18^{a}$ & $52.35 \pm 0.75^{b}$ & $36.67 \pm 0.55^{c}$ & $51.28 \pm 0.13^{\mathrm{b}}$ & 1.66 & $<0.001$ \\
\hline VFA (mM) & $33.77 \pm 0.18^{\mathrm{b}}$ & $31.78 \pm 0.54^{c}$ & $31.62 \pm 1.28^{c}$ & $33.29 \pm 0.59^{b}$ & $30.82 \pm 0.58^{c}$ & $35.69 \pm 0.18^{\mathrm{a}}$ & 0.42 & $<0.01$ \\
\hline - C2 (\% total VFA) & $72.87 \pm 0.00^{c}$ & $74.28 \pm 0.00^{\mathrm{b}}$ & $75.47 \pm 0.01^{\mathrm{b}}$ & $72.53 \pm 0.01^{c}$ & $77.52 \pm 0.00^{\mathrm{a}}$ & $74.79 \pm 0.01^{\mathrm{b}}$ & 0.42 & $<0.001$ \\
\hline - C3 (\% total VFA) & $18.94 \pm 0.01^{\mathrm{a}}$ & $16.74 \pm 0.01^{\mathrm{bc}}$ & $17.08 \pm 0.01^{\mathrm{bc}}$ & $18.11 \pm 0.01^{\mathrm{ab}}$ & $16.08 \pm 0.00^{c}$ & $17.90 \pm 0.01^{\mathrm{ab}}$ & 0.27 & $<0.05$ \\
\hline - C4 (\% total VFA) & $8.19 \pm 0.00^{\mathrm{bc}}$ & $8.99 \pm 0.00^{\mathrm{ab}}$ & $7.45 \pm 0.00^{c}$ & $9.36 \pm 0.01^{\mathrm{a}}$ & $6.40 \pm 0.00^{d}$ & $7.32 \pm 0.00^{c}$ & 0.26 & $<0.001$ \\
\hline - C2:C3 & $3.85 \pm 0.13^{c}$ & $4.44 \pm 0.17^{\mathrm{ab}}$ & $4.43 \pm 0.20^{\mathrm{ab}}$ & $4.01 \pm 0.18^{c}$ & $4.82 \pm 0.07^{a}$ & $4.18 \pm 0.18^{\mathrm{bc}}$ & 0.10 & $<0.001$ \\
\hline $\mathrm{CH}_{4}(\mathrm{mM})$ & $10.42 \pm 0.17^{b}$ & $10.30 \pm 0.27^{b}$ & $10.20 \pm 0.56^{\mathrm{b}}$ & $10.46 \pm 0.23^{b}$ & $10.18 \pm 0.22^{\mathrm{b}}$ & $11.29 \pm 0.19^{a}$ & 0.17 & $<0.001$ \\
\hline $\mathrm{NH}_{3}(\mathrm{mmol} / \mathrm{L})$ & $13.42 \pm 1.03^{\mathrm{d}}$ & $18.95 \pm 1.05^{\mathrm{a}}$ & $17.85 \pm 1.16^{\mathrm{ab}}$ & $17.61 \pm 0.77^{\mathrm{ab}}$ & $16.50 \pm 1.04^{\mathrm{bc}}$ & $15.56 \pm 1.25^{c}$ & 0.65 & $<0.001$ \\
\hline
\end{tabular}

Note: Means in the same column with different superscripts differ significantly $(\mathrm{p}<0.05)$. BP= Bauhinia purpurea, $\mathrm{PI}=$ Pterocarpus indicus, TI= Tamarindus indica, $\mathrm{CM}=$ Calopogonium mucunoides, $\mathrm{MA}=$ Macroptilium atropurpureum, $\mathrm{SG}=$ Stylosanthes guianensis, $\mathrm{DMD}=$ dry matter degradability; $\mathrm{OMD}=$ organic matter degradability; $\mathrm{VFA}=$ volatile fatty acid; $\mathrm{C} 2=$ acetate; $\mathrm{C} 3=$ propionate; $\mathrm{C} 4=$ butyrate; $\mathrm{CH} 4=$ methane, $\mathrm{NH} 3=$ ammonia; $\mathrm{SEM}=$ standard error of mean.

Table 4. Total gas production of tropical legumes at 12, 24, 48, and 72 hours of incubation

\begin{tabular}{|c|c|c|c|c|}
\hline \multirow{2}{*}{ Tropical legumes } & \multicolumn{4}{|c|}{ Time of incubation (hour) } \\
\hline & 12 & 24 & 48 & 72 \\
\hline Bauhinia purpurea & $18.67 \pm 0.47 \mathrm{c}$ & $27.83 \pm 0.94^{c}$ & $34.33 \pm 1.03^{\mathrm{b}}$ & $37.00 \pm 1.63^{\mathrm{bc}}$ \\
\hline Pterocarpus indicus & $19.25 \pm 1.43^{\mathrm{ab}}$ & $28.92 \pm 2.97^{\mathrm{bc}}$ & $34.08 \pm 3.78^{\mathrm{b}}$ & $36.17 \pm 4.03^{\mathrm{bc}}$ \\
\hline Tamarindus indica & $22.08 \pm 1.36^{\mathrm{a}}$ & $31.17 \pm 3.01^{\mathrm{ab}}$ & $35.83 \pm 3.47^{b}$ & $37.25 \pm 3.68^{b c}$ \\
\hline Calopogonium mucunoides & $20.33 \pm 1.84^{b}$ & $30.33 \pm 2.90^{\mathrm{abc}}$ & $36.67 \pm 3.68^{\mathrm{ab}}$ & $39.50 \pm 4.30^{\mathrm{b}}$ \\
\hline Macroptilium atropurpureum & $11.33 \pm 1.31^{\mathrm{d}}$ & $19.33 \pm 2.66^{\mathrm{d}}$ & $27.83 \pm 3.47 \mathrm{c}$ & $31.33 \pm 3.06^{c}$ \\
\hline Stylosanthes guianensis & $19.67 \pm 1.25^{\mathrm{bc}}$ & $32.00 \pm 2.55^{\mathrm{a}}$ & $39.17 \pm 2.95^{\mathrm{a}}$ & $45.92 \pm 6.99^{a}$ \\
\hline SEM & 0.89 & 1.08 & 1.06 & 1.35 \\
\hline P Value & $<0.01$ & $<0.01$ & $<0.01$ & $<0.01$ \\
\hline
\end{tabular}

Note: Means in the same column with different superscripts differ significantly $(\mathrm{p}<0.05) . \mathrm{BP}=$ Bauhinia purpurea, $\mathrm{PI}=$ Pterocarpus indicus, TI= Tamarindus indica, $\mathrm{CM}=$ Calopogonium mucunoides, $\mathrm{MA}=$ Macroptilium atropurpureum, $\mathrm{SG}=$ Stylosanthes guianensis, $\mathrm{a}=$ Production of dissolved fraction gas, $\mathrm{a}+\mathrm{b}=$ maximum gas production at $\mathrm{t}$ which limits to infinity (asymptote), $\mathrm{c}=$ rate of gas production, $\mathrm{SEM}=$ standard error of mean. 
Table 5. Production of dissolved fraction gas (a), maximum gas $(\mathrm{a}+\mathrm{b})$, and rate of gas production (c) of tropical legumes

\begin{tabular}{lccc}
\hline $\begin{array}{r}\text { Tropical } \\
\text { legumes }\end{array}$ & $\mathrm{a}(\mathrm{mL})$ & $\mathrm{a}+\mathrm{b}(\mathrm{mL})$ & $\mathrm{c}(\mathrm{mL} / \mathrm{hour})$ \\
\hline BP & $3.57 \pm 0.43^{\mathrm{c}}$ & $37.79 \pm 0.42^{\mathrm{b}}$ & $0.05 \pm 0.003^{\mathrm{b}}$ \\
PI & $2.97 \pm 0.73^{\mathrm{d}}$ & $36.53 \pm 0.71^{\mathrm{b}}$ & $0.06 \pm 0.01^{\mathrm{ab}}$ \\
TI & $4.77 \pm 0.60^{\mathrm{a}}$ & $37.52 \pm 0.59^{\mathrm{b}}$ & $0.067 \pm 0.01^{\mathrm{a}}$ \\
$\mathrm{CM}$ & $4.48 \pm 0.64^{\mathrm{b}}$ & $40.20 \pm 0.63^{\mathrm{b}}$ & $0.052 \pm 0.004^{\mathrm{b}}$ \\
MA & $2.89 \pm 0.66^{\mathrm{e}}$ & $36.61 \pm 1.05^{\mathrm{b}}$ & $0.027 \pm 0.003^{\mathrm{c}}$ \\
SG & $1.02 \pm 1.62^{\mathrm{f}}$ & $48.03 \pm 1.64^{\mathrm{a}}$ & $0.045 \pm 0.01^{\mathrm{b}}$ \\
SEM & 0.30 & 1.56 & 0.00 \\
P value & $<0.05$ & $<0.05$ & $<0.01$
\end{tabular}

Note: Means in the same column with different superscripts differ significantly $(\mathrm{p}<0.05) . \mathrm{BP}=$ Bauhinia purpurea, $\mathrm{PI}=$ Pterocarpus indicus, $\mathrm{TI}=$ Tamarindus indica, $\mathrm{CM}=$ Calopogonium mucunoides, $\mathrm{MA}=$ Macroptilium atropurpureum, SG= Stylosanthes guianensis, $\mathrm{a}=$ Production of dissolved fraction gas, $\mathrm{a}+\mathrm{b}=$ maximum gas production at $\mathrm{t}$ which limits to infinity (asymptote), $\mathrm{c}=$ rate of gas production, SEM= standard error of mean.

of Calliandra calothyrsus (51.2\%), but lower than that of Leucaena leucocephala (64.4\%) (Jayanegara et al., 2011). Observation of methane gas production showed that S. guianensis produced the highest methane production compared to the other five legumes. There was a positive correlation with a low correlation coefficient between legume ASP and $\mathrm{CH}_{4}$ production. Methane emission has been an important parameter to be considered for a sustainable animal production system since it contributes significantly to the global warming problem (Jayanegara et al., 2018). Therefore, selecting a high quality legume species with a low methane emission has a great potential for animal feeding with primary importance.

Data on the accumulation of $\mathrm{C} 2, \mathrm{C} 3$, and C4 (VFA) were in the range of $30-36 \mathrm{mM}$, that is relatively lower than the result of another in vitro study that is in the range of 42.9-64.7 $\mathrm{mM}$ (Weimer et al., 2011). This low accumulation of VFA may be caused by the decreasing ruminal microbes activity. Fabro et al. (2020) stated that rumen liquid has an impact on gas production. $S$. guianensis produced the highest average total gas production which was in line with the total concentration of VFA produced. S. guianensis legume has a relatively high ASP content compared to the other legumes, with respect to that, S. guianensis produces high gas and VFA. This result is related to the presence of ASP which is a substrate or food for ruminal microbes in their activities. Gas will be produced as a result of a ruminal microbe's metabolic activity. Starch is a raw material for VFA formation by ruminal microbes. In addition, the total phenolics content of $S$. guianensis is relatively low, so the availability of protein that can be fermented by rumen microbes can increase. In contrast, $M$. atropurpureum produced the lowest average total gas production, which was in line with the low concentration of VFA produced. It can be explained that the total gas production directly became the parameter of substrate degradation, then it would be reflected in the concentration of the fermentation product.

Ammonia is needed by ruminants as a precursor for the synthesis and formation of microbial proteins.
Table 6. Correlation matrix (r) between content of sugar and starch and in vitro fermentation characteristics

\begin{tabular}{lcccc}
\hline Variables & Sugar & Starch & Tannin & Protein \\
\hline DMD & $0.203^{\text {ns }}$ & $0.649^{* * *}$ & $-0.380^{\text {ns }}$ & $-0.108^{\text {ns }}$ \\
OMD & $0.293^{\text {ns }}$ & $0.58^{* *}$ & $-0.182^{\text {ns }}$ & $0.179^{\text {ns }}$ \\
VFA & $-0.009^{\text {ns }}$ & $0.155^{\text {ns }}$ & $-0.692^{* *}$ & $-0.027^{\text {ns }}$ \\
$\mathrm{CH}_{4}$ & $-0.186^{\text {ns }}$ & $0.229^{\text {ns }}$ & $-0.390^{\text {ns }}$ & $-0.215^{\text {ns }}$ \\
$\mathrm{NH}_{3}$ & $0.259^{\text {ns }}$ & $0.515^{*}$ & $0.572^{*}$ & $-0.154^{\text {ns }}$ \\
Gas & $0.238^{\text {ns }}$ & $0.60^{* *}$ & $-0.313^{\text {ns }}$ & $0.005^{\text {ns }}$ \\
a+b & $-0.063^{\text {ns }}$ & $0.282^{\text {ns }}$ & $-0.330^{\text {ns }}$ & $-0.233^{\text {ns }}$ \\
$c$ & $0.211^{\text {ns }}$ & $0.476^{*}$ & $0.066^{\text {ns }}$ & $0.160^{\text {ns }}$ \\
\hline
\end{tabular}

Note: $n s=$ No significant differences; ${ }^{*}=$ significantly different $(\mathrm{p}<0.05)$ ${ }^{* *}=$ significantly different $(\mathrm{p}<0.01) ;{ }^{* * *}=$ very significantly different $(\mathrm{p}<0.001) ; \mathrm{DMD}=$ dry matter degradability; $\mathrm{OMD}=$ organic matter degradability; $\mathrm{VFA}=$ volatile fatty acid; $\mathrm{CH}_{4}=$ methane; $\mathrm{NH}_{3}=\mathrm{am}$ monia; $a+b=$ maximum gas production at $t$ which limits to infinity (asymptote); $\mathrm{c}=$ rate of gas production.

Rumen microbes do not have the ability to utilize amino acids directly. Protein is the main factor in influencing ammonia production after being degraded and fermented by rumen microbes. Feed protein is hydrolyzed by proteolytic enzymes, that is produced by proteolytic bacteria, then it is converted into amino acid, and subsequently fermented by catabolism reaction to generate ammonia. The acid soluble polysaccharides content in legumes was positively correlated $(\mathrm{r}=0.515, \mathrm{p}<0.05)$ with ammonia production. Lu et al. (2019) stated that energy rich-diet induces a significant increase in rumen microbial protein yield.

Stylosanthes giuanensis produced the highest maximum gas from shrub legume. The profile of each legume varies according to gas production characteristics. The maximum gas produced by $M$. atropurpureum is low because the production rate was only $0.027 \mathrm{~mL} /$ hour. $P$. indicus also had a gas production rate of 0.06 $\mathrm{mL} /$ hour, although it produced a maximum gas which was relatively the same as $M$. atropurpureum. It can be caused by crude fiber (NDF and ADF) and protein content. Boga et al. (2014) stated that nutrient content and soil salinity could affect in vitro gas production values. Figure 1 shows that each legume species had different gas production characteristics. M. atropurpureum had consistently low gas production compared to the other plants. T. indica had high gas production at the beginning of incubation but decreased along the incubation time. In contrast, the gas production of S. guianensis was high at the beginning until 72 hours of incubation.

Sugar is a carbohydrate component composed of monosaccharides and disaccharides. The relatively soluble sugar content (Ahmed et al., 2013) causes the sugar did not have a significant correlation with in vitro nutrient fermentability. Acid soluble polysaccharides had a positive correlation with the degradability of dry matter and organic substrates (Table 6).

As much as $80 \%$ of ruminant protein requirements are met by microbial protein synthesis. Rumen microbes utilize sources of NPN (non-protein nitrogen) to be converted into ammonia $\left(\mathrm{NH}_{3}\right)$ through a deamination process. Rumen microbes require starch as an energy 
source in the deamination process. Furthermore, ammonia is converted into proteins that can be utilized by host animals through the process of microbial protein synthesis. This process is carried out by rumen microbes. Similar to the deamination process, rumen microbes also need energy sources to support microbial protein synthesis activities. Starch is a source of non-structural carbohydrates that are easily utilized by the rumen microbes compared to structural carbohydrates (cellulose and hemicellulose). This study showed that the presence of ASP was positively correlated with the amount of ammonia produced.

Rumen microbes digest starch in anaerobic conditions. Jayanegara et al. (2018) mentioned that one of the fermentation products by rumen microbes is gas, such as carbon dioxide $\left(\mathrm{CO}_{2}\right)$ and methane $\left(\mathrm{CH}_{4}\right)$. The results showed a positive correlation between the presence of starch and total gas produced at 24 hours incubation time. Total gas production at a certain time determines the rate of gas production. Another factor that can influence the rate of gas production is the type of substrate digested. Moreover, Gallo et al. (2018) revealed that the particle size of the substrate influenced the rate of gas production.

The presence of tannin measured as total phenolics in tropical legumes has both positive and negative sides. Tannin is a limiting factor for protein degradability. Tannin can bind to protein and reduce the availability of protein (Kondo et al., 2014). Tannin binds to protein to form complex bonds of tannin proteins. Buccioni et al. (2015) stated that tannin protects protein from degradation by rumen microbes (protease enzyme). Tannin converts RDP to RUP. In other words, the presence of tannins reduces the availability of nutrients fermented by rumen microbes. The biological activity of tannin determines the amount of tannin protection against the substrate. The results (Table 5) showed that tannin had a negative correlation with total VFA production. Total VFA production is a product of fermentation by microbes in the rumen. Therefore, if the availability of nutrients in the rumen is limited (due to tannin), the VFA produced is also limited.

One positive side of tannin is the decline in methane gas production. Several studies (Bueno et al., 2015; Jayanegara et al., 2015; Szczechowiak et al., 2016) showed that tannin could reduce methane gas production in the digestive system of ruminants. The mechanism of tannin in reducing methane gas production can be categorized as a direct and indirect mechanism. The direct mechanism occurs because tannin can inhibit the activity of metanobacterium bacteria (methanogenesis). An indirect mechanism occurs when tannins inhibit the digestion of fiber in feed because fiber digestion can produce hydrogen $\left(\mathrm{H}_{2}\right)$. In addition to producing methane, metanobacterium bacteria play a role in digesting cellulose, by working with cellulolytic bacteria. Metanobacterium activity can be reduced by utilizing hydrogen for the other activities, such as biohydrogenation. The reaction of hydrogen and carbon dioxide $\left(\mathrm{CO}_{2}\right)$ produces methane and water (Castagninoa et al., 2014).
Tannin changes the protein that is easily degraded by rumen microbes (Rumen Degradable Protein) into protein that is not easily degraded by rumen microbes (Rumen Undegradable Protein). In this case, tannin is binding to protein so that the protein directly bypasses the small intestine. NPN content (non-protein nitrogen) in fresh legumes was approximately $10-15 \%$ of $\mathrm{CP}$ (mainly peptides, free amino acids, and nitrates), and this amount of NPN is an indicator of an increase in the value of crude protein (Solati et al., 2018). In this study, $\mathrm{CP}$ levels did not have a significant correlation with ammonia and total phenolics $(\mathrm{p}>0.05)$. High $\mathrm{CP}$ content influences the amount of NPN. Tannin has an important role in protecting plants against insects and fungi, as well as protecting the plant germination (Barbehenn et al., 2011).

Orthogonal contrast test was performed to see whether there was a difference between tree and shrub legumes and legumes with moderate and low tannin content in each of in vitro fermentation parameters. Statistically, the significant differences appear because the data in treatment has a good uniformity (Payadnya \& Jayantika, 2018). Almost all parameters present significant differences because in one group, tree legumes or shrub legumes show a good uniformity as well as a legume with low and moderate tannin. Otherwise, ammonia level does not present a significant difference between a tree and shrub legume, it appears because the data have high variation. Consequently, it can enlarge error (Payadnya \& Jayantika, 2018).

\section{CONCLUSION}

Sugar content of legumes did not have a significant relationship to the characteristics of fermentation, and on the contrary, starch had a very close relationship to the parameters of fermentation (total gas production, rate of gas production, and degradability of dry and organic matter and ammonia). The tannin content measured as total phenolics had a close relationship with the production of VFA and ammonia. Tree legumes have better digestibility than shrub legumes.

\section{CONFLICT OF INTEREST}

Anuraga Jayanegara and Anjas Asmara bin Samsudin serve as editors of the Tropical Animal Science Journal, but have no role in the decision to publish this article. The authors also declare that there is no conflict of interest with any financial, personal, or other relationships with other people or organization related to the material discussed in the manuscript.

\section{ACKNOWLEDGEMENT}

The first author would like to thank the Indonesia Endowment Fund for Education, Ministry of Finance for providing scholarship. All authors would like to thank the Faculty of Animal Sciences, IPB University and Faculty of Agriculture Universiti Putra Malaysia (UPM) for supporting this research. 


\section{REFERENCES}

Ahmed, S., A. Minuti, \& P. Bani. 2013. In vitro rumen fermentation characteristics of some naturally occurring and synthetic sugars. Ital. J. Anim. Sci. 12: 359-365. https://doi. org/10.4081/ijas.2013.e57

Alcázar-alay, S. C. \& M. A. A. Meireles. 2015. Physicochemical properties, modifications and applications of starches from different botanical sources. Food Sci. Technol. 35: 215-236. https://doi.org/10.1590/1678-457X.6749

AOAC. 2005. Official Methods of Analysis of AOAC International. $18^{\text {th }}$ ed. Assoc. Off. Anal. Chem., Arlington.

Azizi, A., A. Sharifi, H. Fazaeli, A. Azarfar, A. Jonker, \& A. Kiani. 2020. Effect of transferring lignocellulose-degrading bacteria from termite to rumen fluid of sheep on in vitro gas production, fermentation parameters, microbial populations and enzyme activity. J. Integr. Agric. 19: 13231331. https://doi.org/10.1016/S2095-3119(19)62854-6

Barbehenn, R. V. \& C. P. Constabel. 2011. Tannins in plant-herbivore interactions. Phytochemistry. 72: 1551-1565. https:// doi.org/10.1016/j.phytochem.2011.01.040

Bawazeer, S., A. M. Ali, A. Alhawiti, A. Khalaf, C. Gibson, J. Tusiimire, \& D. G. Watson. 2017. A method for the analysis of sugars in biological systems using reductive amination in combination with hydrophilic interaction chromatography and high resolution mass spectrometry. Talanta. 166: 75-80. https://doi.org/10.1016/j.talanta.2017.01.038

Boga, M., S. Yurtseven, U. Kilic, S. Aydemir, \& T. Polat. 2014. Determination of nutrient contents and in vitro gas production values of some legume forages grown in the harran plain saline soils. Asian Australas. J. Anim. Sci. 27: 825-831. https://doi.org/10.5713/ajas.2013.13718

Buccioni, A., M. Pauselli, C. Viti, S. Minieri, G. Pallara, V. Roscini, S. Rapaccini, M. T. Marinucci, P. Lupi, G. Conte, \& M. Mele. 2015. Milk fatty acid composition, rumen microbial population, and animal performances in response to diets rich in linoleic acid supplemented with chestnut or quebracho tannins in dairy ewes. J. Dairy Sci. 98:1145-1156. https://doi.org/10.3168/jds.2014-8651

Bueno, I. C. S., R. A. Brandi, R. Franzolin, G. Benetel, G. M. Fagundes, A. L. Abdalla, H. Louvandini, \& J. P. Muir. 2015. In vitro methane production and tolerance to condensed tannins in five ruminant species. Anim. Feed Sci. Technol. 205: 1-9. https://doi.org/10.1016/j.anifeedsci.2015.03.008

Cabeza, I., T. Waterhouse, S. Sohi, \& J. A. Rooke. 2018. Effect of biochar produced from different biomass sources and at different process temperatures on methane production and ammonia concentrations in vitro. Anim. Feed Sci. Technol. 237: 1-7. https://doi.org/10.1016/j.anifeedsci.2018.01.003

Castagninoa, P. S., J. D. Messanaa, G. Fiorentini, R. B. de Jesus, E. S. Vitoa, I. P. C. Carvalhoa, \& T. T. Berchielli. 2014. Glycerol combined with oils did not limit biohydrogenation of unsaturated fatty acid but reduced methane production in vitro. Anim. Feed Sci. Technol. 201: 14-24. https://doi.org/10.1016/j.anifeedsci.2014.12.004

Dickhoefer, U., S. Glowacki, C. A. Gomez, \& J. M. CastroMontoya. 2018. Forage and protein use efficiency in dairy cows grazing a mixed grass-legume pasture and supplemented with different levels of protein and starch. Livest. Sci. 216: 109-118. https://doi.org/10.1016/j.livsci.2018.08.004

Duan, D. X., E. Donne, Q. Liu, D. C. Smith, \& F. Ravenelle. 2012. Potentiometric titration for determination of amylose content of starch - A comparison with colorimetric method. Food Chem. 130: 1142-1145. https://doi.org/10.1016/j. foodchem.2011.07.138

Fabro, C., C. Sarnataro, \& C. M. Spanghero. 2020. Impacts of rumen fluid, refrigerated or reconstituted from a refrigerated pellet, on gas production measured at $24 \mathrm{~h}$ of fermentation. Anim. Feed Sci. Tech. 268: 1-7. https://doi. org/10.1016/j.anifeedsci.2020.114585

Focant, M., E. Froidmont, Q. Archambeau, Q. C. Dang Van, \& Y. Larondelle. 2018. The effect of oak tannin (Quercus robur) and hops (Humulus lupulus) on dietary nitrogen efficiency, methane emission, and milk fatty acid composition of dairy cows fed a low-protein diet including linseed. J. Dairy Sci. 102: 1144-1159. https://doi.org/10.3168/ jds.2018-15479

Gallo, A., G. Giuberti, A. S. Atzori, \& F. Masoero. 2018. Short communication: In vitro rumen gas production and starch degradation of starch-based feeds depend on mean particle size. J. Dairy Sci. 101: 6142-6149. https://doi.org/10.3168/ jds.2017-13944

Hall, M. B. 2014. Selection of an empirical detection method for determinationof water-soluble carbohydrates in feedstuffs for applicationin ruminant nutrition. Anim. Feed Sci. Tech. 198: 28-37. https://doi.org/10.1016/j.anifeedsci.2014.08.009

Hatew, B., J. W. Cone, W. F. Pellikaan, S.C. Podesta, A. Bannink, W. H. Hendriks, \& J. Dijkstra. 2015. Relationship between in vitro and in vivo methane production measured simultaneously with different dietary starch sources and starch levels in dairy cattle. Anim. Feed. Sci. Technol. 202: 20-31. https://doi.org/10.1016/j.anifeedsci.2015.01.012

Heinritz, S. N., S. D. Martens, P. Avilaa, \& S. Hoedtke. 2012. The effect of inoculant and sucrose addition on the silage quality of tropical forage legums with varying ensilability. Anim. Feed Sci. Technol. 174: 201-210. https://doi. org/10.1016/j.anifeedsci.2012.03.017

Jayanegara, A., E. Wina, C. R. Soliva, S. Marquardt, M. Kreuzera, \& F. Leiber. 2011. Dependence of forage quality and methanogenic potential of tropical plants on their phenolic fractions as determined by principal component analysis. Anim. Feed Sci. Technol. 163: 231-243. https://doi. org/10.1016/j.anifeedsci.2010.11.009

Jayanegara, A., G. Goel, H. P. S. Makkar, \& K. Becker. 2015. Divergence between purified hydrolysable and condensed tannin effects on methane emission, rumen fermentation and microbial population in vitro. Anim. Feed Sci. Technol. 209: 60-68. https://doi.org/10.1016/j.anifeedsci.2015.08.002

Jayanegara, A., K. A. Sarwono, M. Kondo, H. Matsui, M. Ridla, E.B. Laconi, \& Nahrowi. 2018. Use of 3-nitrooxypropanol as feed additive for mitigating enteric methane emissions from ruminants: a meta-analysis. Ital. J. Anim. Sci. 17: 650656. https://doi.org/10.1080/1828051X.2017.1404945

Junior, A. M. L., F. J. C. Fracetto, J. S. Ferreira, M. B. Silva, \& G. G. M. Fracetto. 2020. Legume-based silvopastoral systems drive $\mathrm{C}$ and $\mathrm{N}$ soil stocks in a subhumid tropical environment. Catena. 189: 1-8. https://doi.org/10.1016/j. catena.2020.104508

Kondo, M., Y. Hirano, N. Ikai, K. Kita, A. Jayanegara, H.-O. Yokota. 2014. Assessment of anti-nutritive activity of tannins in tea by-products based on in vitro rumen fermentation. Asian Australas. J. Anim. 27: 1571-1576. https://doi. org/10.5713/ajas.2014.14204

Lu, Z., Z. Xu, Z. Shen, Y. Tian, \& H. Shen. 2019. Dietary energy level promotes rumen microbial protein synthesis by improving the energy productivity of the ruminal microbiome. Front. Microbiol. 10: 1-14. https://doi.org/10.3389/ fmicb.2019.00847

Menke, K.H. \& H. Steingass. 1988. Estimation of the energetic feed value obtained from chemical analysis and in vitro gas production using rumen fluid. Anim. Res. Dev. 28: 7-55.

Moss, A.R., J. P. Jouany, \& J. Newbold. 2000. Methane production by ruminants: Its contribution to global warming. Ann Zootech. 49: 231-253. https://doi.org/10.1051/ animres:2000119

Payadnya, I. P. A. A. \& I. G. A. N. T. Jayantika. 2018. Panduan Penelitian Eksperimen beserta Analisis Statistik dengan SPSS. Deepublish, Yogyakarta. 
Petchidurai, G., J. A. Nagoth, M. S. John, K. Sahayaraj, N. Murugesan, \& S. Pucciarelli. 2019. Standardization and quantification of total tannins, condensed tannin and soluble phlorotannins extracted from thirty-two drifted coastal macroalgae using high performance liquid chromatography. Bioresour. Technol. 7: 1-6. https://doi.org/10.1016/j. biteb.2019.100273

Pino, F. \& A. J. Heinrichs. 2016. Effect of trace minerals and starch on degradability and rumen fermentation in diets for dairy heifers. J. Dairy Sci. 99: 1-1. https://doi. org/10.3168/jds.2015-10034

Riadi, E. 2016. Statistika Penelitian (Analisis Manual dan IBM SPSS). $1^{\text {st }}$ ed. Andi Publisher, Jakarta.

Solati, Z., K. Manevski, U. Jørgensen, R. Labouriau, S. Shahbazi, \& P. E. Lærke. 2018. Crude protein yield and theoretical extractable true protein of potential biorefinery feedstocks. Ind Crop Prod. 115: 214-22. https://doi. org/10.1016/j.indcrop.2018.02.010
Szczechowiak, J., M. S. Strabel, M. El-Sherbiny, E. P. Kamczyc, P. Pawlak, \& A. Cieslak. 2016. Rumen fermentation, methane concentration and fatty acid proportion in the rumen and milk of dairy cows fed condensed tannin and or fishsoybean oils blend. Anim. Feed Sci. Technol. 216: 93-107. https://doi.org/10.1016/j.anifeedsci.2016.03.014

Van Soest, P. J., J. B. Robertson, \& B. A. Lewis. 1991. Methods for dietary fiber, neutral detergent fiber, and nonstarch polysaccharides in relation to animal nutrition. J. Dairy Sci. 74: 3583-3597. https://doi.org/10.3168/jds. S0022-0302(91)78551-2

Weimer, P. J., D. M. Stevenson, D. R. Mertens, \& M. B. Hall. 2011. Fiber digestion, VFA production, and microbial population changes during in vitro ruminal fermentations of mixed rations by monensin-adapted and unadapted microbes. Anim. Feed Sci. Technol. 169: 68-78. https://doi. org/10.1016/j.anifeedsci.2011.06.002 